\title{
Distribution and population structure of endobacteria in arbuscular mycorrhizal fungi at North Atlantic dunes
}

\author{
Olga A. Lastovetsky ${ }^{1} \cdot$ Ezekiel $\mathrm{Ahn}^{2} \cdot$ Stephen J. Mondo ${ }^{2} \cdot$ Kevin H. Toomer ${ }^{2} \cdot$ Aolin Zhang $^{2} \cdot$ Lynn M. Johnson $^{3}$. \\ Teresa E. Pawlowska $\mathbb{1}^{2}$
}

Received: 14 November 2017 / Revised: 29 June 2018 / Accepted: 6 July 2018 / Published online: 10 August 2018

(c) International Society for Microbial Ecology 2018

\begin{abstract}
Arbuscular mycorrhizal fungi (AMF, Glomeromycotina), in addition to forming symbioses with the majority of land plants, harbor vertically transmitted endosymbiotic bacteria 'Candidatus Glomeribacter gigasporarum' $(\mathrm{Ca} \mathrm{Gg})$ and 'Candidatus Moeniiplasma glomeromycotorum' $(\mathrm{CaMg}) . \mathrm{CaGg}$ is a nonessential mutualist of AMF, whereas the lifestyle of $\mathrm{CaMg}$ is unknown. To start unraveling the interactions between AMF and their endosymbionts in nature, we examined diversity and distribution of AMF-associated endobacteria in North Atlantic dunes at Cape Cod. Of nearly 500 foredune AMF isolates successfully genotyped during a systematic study, 94\% were classified as Gigasporaceae. Two percent of all AMF spores harbored $\mathrm{CaGg}$, and $88 \%$ contained $\mathrm{CaMg}$. $\mathrm{CaGg}$ was found only in the Gigasporaceae, whereas $\mathrm{CaMg}$ was present in Gigasporaceae, Acaulosporaceae, and Diversisporaceae. Incidence of $\mathrm{CaGg}$ across AMF was not affected by any of the environmental parameters measured, whereas distribution of $\mathrm{CaMg}$ in one of the fungal hosts was impacted by plant density. $\mathrm{CaMg}$ populations associated with AMF individuals displayed high levels of genetic diversity but no evidence of gene flow, suggesting that host physical proximity is not sufficient to facilitate horizontal transmission of $\mathrm{CaMg}$. Finally, in addition to a novel lineage of $\mathrm{CaGg}$, we discovered that AMF likely harbor Burkholderia-related bacteria with close phylogenetic affinity to free-living Burkholderia and endobacteria of other Mucoromycota fungi.
\end{abstract}

\section{Introduction}

Arbuscular mycorrhizal fungi (AMF, subphylum Glomeromycotina) form mutualistic associations with roots of the majority of terrestrial plants [1]. They provision plants with

Accession numbers Sequences generated in this study are deposited at GenBank under accession numbers: MG493487-MG494246 (Table S5).

Electronic supplementary material The online version of this article (https://doi.org/10.1038/s41396-018-0246-2) contains supplementary material, which is available to authorized users.

Teresa E. Pawlowska

tep8@cornell.edu

1 Graduate Field of Microbiology, Cornell University, Ithaca, NY 14853, USA

2 School of Integrative Plant Science, Plant Pathology \& PlantMicrobe Biology, Cornell University, Ithaca, NY 14853, USA

3 Cornell Statistical Consulting Unit, Cornell University, Ithaca, NY 14853, USA mineral nutrients, such as phosphorus and nitrogen, in exchange for photosynthesis-derived carbon [1]. Consequently, AMF play important roles in functioning of terrestrial ecosystems and global nutrient cycling, and are of rising interest in sustainable agriculture as alternatives to non-renewable mineral fertilizers [2, 3].

For decades, AMF have been known to harbor morphologically diverse endosymbiotic bacteria in their hyphae and spores [4]. Among them, 'Candidatus Glomeribacter gigasporarum' ( $\mathrm{CaGg}$, Betaproteobacteria) stands out as the most extensively studied endobacterium of AMF [5]. $\mathrm{CaGg}$ resides in fungus-derived vesicles inside hyphae and spores of AMF in the family Gigasporaceae. AMF spores that harbor $\mathrm{CaGg}$ have been shown to produce longer presymbiotic hyphae than spores that are $\mathrm{CaGg}$-free [6], a phenomenon attributed to the ability of $\mathrm{CaGg}$ to prime energy metabolism of the fungus [7]. Despite the ancient origin of the $\mathrm{CaGg}-\mathrm{Gigasporaceae}$ association, $\mathrm{CaGg}$ remains nonessential to its fungal host [6, 8]. In other words, AMF display facultative dependence on $\mathrm{CaGg}$. In turn, $\mathrm{CaGg}$ cannot be cultivated in separation from AMF [9], and is obligately dependent on its host [10]. 
Importantly, the $\mathrm{Ca} \mathrm{Gg}$-Gigasporaceae symbiosis does not appear to be in transition toward a reciprocally obligate state, in which $\mathrm{CaGg}$ is essential to AMF survival, as would be expected in associations where endosymbionts are vertically transmitted within host populations [8]. As a consequence, evolutionary stability of the $\mathrm{CaGg}$-Gigasporaceae association in its current non-reciprocally obligate form was hypothesized to be the result of shifting environmental conditions, whereby only certain environments, such as those requiring extensive pre-symbiotic hyphal proliferation to contact the plant host, would favor $\mathrm{CaGg}$ presence in AMF [8]. However, the exact conditions that support $\mathrm{CaGg}$ incidence in AMF are unknown due to lack of ecological studies.

Another endobacterium of yet unknown lifestyle, which AMF harbor, has been recently named 'Candidatus Moeniiplasma glomeromycotorum' ( $\mathrm{CaMg}$, Mollicutes) [11, 12]. Its metabolic profile and molecular evolution patterns suggest that $\mathrm{CaMg}$ might be a parasite of AMF [13, 14]. Importantly, $\mathrm{CaMg}$ and $\mathrm{Ca} \mathrm{Gg}$ can co-exist and form an intracellular 'microbiome' of AMF [14, 15]. Similar to $\mathrm{Ca} \mathrm{Gg}, \mathrm{CaMg}$ is vertically transmitted via fungal spores [11]. However, in contrast to $\mathrm{CaGg}$, which has only been found in the family Gigasporaceae, $\mathrm{CaMg}$ is widely distributed among phylogenetically distinct AMF lineages [11, 12]. Populations of $\mathrm{CaMg}$ in AMF isolates/spores/ operational individuals exhibit unexpected intra-host genetic diversity [11-15]. Based on genomic and molecular evolution analyses, this genetic diversity is thought to be the result of symbiont horizontal transmission and recombination $[13,14,16]$.

Our knowledge of the biology of AMF-associated endobacteria, their population structure, and distribution across hosts comes primarily from analyses of culture collection-derived fungal isolates, and little is known about these endobacteria in natural populations of AMF. In the present study, we set out to examine the natural distribution of $\mathrm{Ca \textrm {Gg }}$ and $\mathrm{CaMg}$ in AMF in the North Atlantic dune environment with a particular focus on: (1) surveying incidence of endobacteria in AMF, (2) exploring the effect of environmental factors on the association between AMF and endobacteria, and (3) assessing diversity of $\mathrm{CaGg}$ and $\mathrm{CaMg}$.

The North Atlantic dune ecosystem is well suited for addressing questions concerning AMF and their endobacteria. Previous studies suggested that coastal foredune areas are dominated by AMF representing the family of Gigasporaceae [17-21], a group known to frequently harbor $\mathrm{CaGg}$ [8]. Abundance of AMF spores reaches maximum in late fall, when they can be isolated directly from field samples without the need for enrichment in trap cultures $[17,22]$. Working directly with such field collected spores enables reliable quantification of endobacteria occurrence within AMF. As an early succession system, which is exposed to harsh environmental conditions, foredunes differ from many other natural terrestrial systems in having low plant diversity [23]. North Atlantic foredune plant communities are dominated by a native perennial pioneer species Ammophila breviligulata, American beachgrass [24, 25]. This near monoculture offers a convenient model in which the impact of plant community structure on AMF diversity is expected to be minimal, allowing to isolate effects of other variables. Specifically, steep environmental gradients, which extend from the ocean inland, permit for assessment of environmental impacts at small spatial scales. Typically, salinity and environmental disturbances, such as wind and substrate mobility, decrease inland from the ocean, whereas biotic pressures increase [23]. As a consequence, AMF closer to the ocean are expected to be exposed to higher abiotic pressure and disturbances relative to fungi farther away.

Our pilot survey of AMF at the Cape Cod National Seashore revealed presence of both $\mathrm{CaGg}$ and $\mathrm{CaMg}$. Subsequent systematic sampling in the foredunes, which display the steepest environmental gradients and lowest plant diversity, indicated that $\mathrm{Ca} \mathrm{Gg}$ and $\mathrm{CaMg}$ differed in their distribution patterns across AMF. Incidence of $\mathrm{CaGg}$ in spores of AMF was not affected by environmental parameters, whereas plant density significantly impacted distribution of $C a \mathrm{Mg}$. As in previous studies [12-15], individual isolates of dune AMF harbored diverse populations of $\mathrm{CaMg}$. However, the lack of evidence of mixing between $\mathrm{CaMg}$ from different dune AMF suggested that host physical proximity is not sufficient for horizontal transmission of $\mathrm{CaMg}$. Finally, in addition to a novel clade of $\mathrm{CaGg}$, we discovered bacteria previously not known to be associated with Glomeromycotina, and likely hosted inside AMF hyphae and spores. These Burkholderiarelated bacteria cluster phylogenetically with free-living Burkholderia and endobacteria of other Mucoromycota fungi.

\section{Materials and methods}

\section{Pilot survey}

To survey the diversity of AMF and their endobacteria at North Atlantic dunes, samples were collected haphazardly from diverse habitats in the Province Lands area of the Cape Cod National Seashore on 11 November 2010. Sampled habitats included foredunes (F, 10 samples), backdunes (B, 6 samples), transitionary dune-woodland areas (M, 10 samples), and woodlands (W, 7 samples). The Edelman auger $\varnothing 7 \mathrm{~cm}$ (Agrisearch Equipment) was used after removing the topmost layer of $20-40 \mathrm{~cm}$ of sand to reach the zone of 
actively growing roots. A total of 33 soil samples were transported to the lab on ice, air dried, and stored at $4{ }^{\circ} \mathrm{C}$ until further processing.

\section{Systematic sampling}

To link diversity of AMF and their endobacteria with environmental variables, samples were collected in a systematic manner from a foredune area dominated by $A$. breviligulata $\left(42^{\circ} 4^{\prime} 50.2^{\prime \prime} \mathrm{N} 70^{\circ} 13\right.$ '2.4' $\left.\mathrm{W}\right)$ on 3 November 2013. Four transects were laid out starting from the edge of vegetation at the seaward side (corresponding to the end of the beach) and extending $100 \mathrm{~m}$ inland (Figure S1). Transects were placed 10,20 , and $40 \mathrm{~m}$ apart (10 $\mathrm{m}$ between Transect 1 and 2; $20 \mathrm{~m}$ between Transect 2 and 3; $40 \mathrm{~m}$ between Transect 3 and 4). A total of 44 samples were collected. Samples were taken every $10 \mathrm{~m}$ by collecting the soil around a plant nearest to each $10 \mathrm{~m}$ mark. These samples were used for AMF spore extractions and soil parameter analyses, as described further. At each sampling point, the following was recorded: (1) total number of individual plants in a $70 \mathrm{~cm}$ radius around the area of soil sampling, (2) distance to four nearest plants in the $70 \mathrm{~cm}$ radius around the area of soil sampling, later averaged to give average nearest neighbor distance (NND), and (3) total number of non-A. breviligulata plants. These parameters were used to estimate total plant density at each sampling point as well as dominance of $A$. breviligulata over other plants.

\section{Spore extraction, collection, and decontamination}

We used wet sieving and decanting followed by $2 \mathrm{M}$ sucrose centrifugation to extract AMF spores from $50 \mathrm{~g}$ of air-dried soil suspended in $200 \mathrm{ml}$ water as described by Daniels and Skipper [26]. Spores were collected on $0.45 \mu \mathrm{m}$ gridded nitrate cellulose filters and selected for further processing at random under magnification following Moebius-Clune et al. [27]. In brief, the grid on the filter was used to define a transect line along which spores were sampled, collecting the spore closest to the grid intersection. To estimate the number of spores (isolates) to be genotyped per sample in order to obtain the total diversity of the population from that sample, we generated collector's curves in MOTHUR [28]. We found that successful genotyping of \pm 8 spores would encompass the AMF diversity in that sample at $0.05 \%$ cutoff. However, to be conservative, we aimed at surveying at least 10 spores per sample. Notably, this was not possible for all samples, as, for example, spores extracted from samples at $0 \mathrm{~m}$ away from the beach were difficult to genotype. Selected spores were decontaminated individually as in Mondo et al. [8]. In brief, spores were sequentially washed with $1 \mathrm{mM}$ and $50 \mathrm{mM}$
$\mathrm{H}_{2} \mathrm{O}_{2}$, then with $4 \%$ chloramine $\mathrm{T}$, followed by a final wash with sterile nanopure water.

\section{AMF spore identification}

Following surface decontamination, each spore was crushed with a pipet tip to release its contents. Total spore DNA was whole-genome amplified using Illustra ${ }^{\mathrm{TM}}$ GenomiPhi-V2 kit (GE Healthcare), and the 1/20 diluted product was used for PCR. A fragment of the fungal 28S ribosomal RNA (rRNA) gene was PCR amplified from individual spores with primers LR1 and NDL22 [29] (Table S1) using JumpStart RedTaq DNA Polymerase Master Mix (Sigma), as described in Mondo et al. [8]. PCR products were cycle sequenced with the BigDye Terminator 3.1 Cycle Sequencing Kit (Applied Biosystems) and analyzed at the Cornell University Biotechnology Resource Center on an ABI 3730xl DNA Analyzer (Applied Biosystems) after purification by Sephadex ${ }^{\mathrm{TM}}$ filtration, using the Performa ${ }^{\circledR}$ DTR Ultra 96-Well Plate Kit (EdgeBio, Gaithersburg, MD). DNA sequences were edited in Geneious 9.1.2 (Biomatters Ltd), aligned with MUSCLE [30], and grouped into operational taxonomic units (OTUs) at $95 \%$ similarity cutoff [27] using MOTHUR [28]. Because MOTHUR algorithms capture sequence diversity derived from degenerate bases, the majority of OTUs were singletons, that is, they were composed of a single sequence. To avoid overestimating the AMF diversity due to such singleton OTUs, we conducted further phylogenetic analyses in which we clustered the representative sequences from each OTU with reference AMF sequences to form statistically supported virtual taxonomic units (VTUs).

\section{Screening for endobacteria}

AMF spores were screened individually for incidence of $\mathrm{Ca} \mathrm{Gg}$ by PCR with Burkholderia-specific primers amplifying a portion of the 23S rRNA gene $[8,31]$ (Table S1), followed by amplicon sequencing, as described above. $\mathrm{CaMg}$ was detected by gel electrophoresis of PCR products generated with $\mathrm{CaMg}$-specific primers targeting a portion of the 16S rRNA gene [12] (Table S1). To dissect intra-host diversity of $\mathrm{CaMg}$, its $16 \mathrm{~S}$ rRNA sequences were subcloned for sequencing after PCR amplification with $\mathrm{CaMg}$-specific primers [12] and Phusion High-Fidelity DNA polymerase (New England Biolabs) under conditions of 5-min initial denaturation at $98^{\circ} \mathrm{C}$ followed by 15 cycles of $10 \mathrm{~s}$ at $98^{\circ}$ C, $30 \mathrm{~s}$ at $50{ }^{\circ} \mathrm{C}$, and $1 \mathrm{~min}$ at $72{ }^{\circ} \mathrm{C}$, followed by a final extension of $10 \mathrm{~min}$ at $72{ }^{\circ} \mathrm{C}$. Amplicons were cloned using the TOPO TA Cloning Kit for Sequencing (Invitrogen Life Technologies). Plasmid DNA from recombinant bacterial colonies was amplified using the Illustra TempliPhi 100/500 DNA Amplification Kit (GE Healthcare Life Sciences). 
Plasmid inserts were cycle-sequenced using $\mathrm{T} 3$ and $\mathrm{T} 7$ primers and analyzed as described above. Cloned $\mathrm{CaMg}$ sequences were clustered at $94 \%$ similarity level [11], followed by phylogeny reconstruction including the representative sequence from each OTU.

\section{Phylogeny reconstructions}

All DNA sequences were aligned using MUSCLE [30]. Phylogenies were reconstructed under the $G T R+I+\Gamma$ nucleotide substitution model implemented in MrBayes 3.2 .5 [32], with a $25 \%$ burn-in and the average standard deviation of split frequencies $(<0.01)$ used as a convergence diagnostic.

\section{Soil chemistry analyses}

Soil samples collected during systematic foredune sampling were air dried at room temperature and stored at $4{ }^{\circ} \mathrm{C}$ until analyzed at the Cornell Nutrient Analysis Laboratory (tests $\# 1060$ and \#1880). Details of the procedures are described in Moebius-Clune et al. [33]. In brief, nutrients were extracted from soil by shaking with Modified Morgan's solution and filtered through a paper filter. The filtrate was analyzed on an inductively coupled plasma emission spectrometer (ICP, Spectro Arcos) for macro- and microelements. $\mathrm{pH}$ of a 2:1 suspension of water and soil was determined using a Lignin $\mathrm{pH}$ robot. Soluble salts were extracted in a 1:1 soil-water suspension, and the electrical conductivity of the supernatant measured with a calibrated conductivity meter. Three soil samples from each transect were analyzed corresponding to distances 0,40 , and $100 \mathrm{~m}$ from the beach.

\section{Statistical analyses}

Linear regression was used to examine the relationship between distance from the beach and different environmental variables, including vegetation and soil chemistry characteristics. To assess the impact of soil parameters on incidence endobacteria in AMF spores, soil chemistry data from samples collected at 0,40 , and $100 \mathrm{~m}$ from the beach were extrapolated, separately for each transect, to the remaining samples using two different methods: (i) linear interpolation values were computed for each missing distance from the beach based on soil chemistry parameters at distances 0,40 , and $100 \mathrm{~m}$, and (ii) LOESS curve was fitted to the soil chemistry parameters at distances 0,40 , and 100 $\mathrm{m}$ versus distance relationship, and values were computed for the remaining missing distances.

Influence of environmental parameters on endobacteria incidence in AMF spores was analyzed using the lsmeans and lme4 packages in R. General linearized mixed models with binomial distribution were used to model $\mathrm{CaGg}$ and $\mathrm{CaMg}$ incidence in AMF spores. Environmental variables (plant density, dominance of $A$. breviligulata, soil salinity, and $\mathrm{pH}$ ) were modeled as fixed effects. To account for variability between and within transects, transect was modeled as a random effect. To account for variability between and within each sampling point within a transect, distance was modeled as a random effect nested within transect. The resulting model accounted for potential correlation in endobacteria incidence between transects and between sampling points within transects. All environmental parameters, except distance, were modeled as continuous variables. Distance was modeled as a factor variable because log odds of endobacteria incidence did not appear to be a linear function of distance. Significance of distance was tested with a likelihood ratio test. Post-hoc pairwise comparisons between distances were performed using Tukey adjustments for multiple comparisons. Influence of soil chemistry parameters (soluble salts, sodium, calcium, and $\mathrm{pH}$ ) on incidence of endobacteria within AMF spores was modeled three independent times, using either only the data that were obtained for distances $0,40,100 \mathrm{~m}$, or the values from the two different extrapolations described above.

\section{Analysis of molecular diversity}

To quantify the extent of diversity among $\mathrm{CaMg}$ genotypes, we conducted hierarchical analysis of molecular variance (AMOVA) implemented in Arlequin 3.5 [34]. We tested the null hypothesis that any variation among $\mathrm{CaMg}$ is due to random sampling. To estimate variance components and $\Phi$ statistics, which are $F$ statistic analogs and reflect the correlations of genotypic diversity at different levels of hierarchical subdivision, we used p-distances computed from the alignment of the 16S rRNA gene haplotypes found in CaMg associated with VTU Gigaspora GAR and VTU Acaulospora that co-occurred spatially. The specific $\Phi$ statistics were: (i) $\Phi_{\mathrm{ST}}$, the correlation of the molecular diversity of random $\mathrm{CaMg}$ genotypes within $\mathrm{AMF}$ isolates relative to the correlation of random pairs of genotypes drawn from the entire $C a \mathrm{Mg}$ diversity, (ii) $\Phi_{\mathrm{SC}}$, the correlation of random $\mathrm{CaMg}$ genotypes among $\mathrm{AMF}$ isolates relative to the correlation of random pairs of $\mathrm{CaMg}$ genotypes drawn from a AMF VTU, and (iii) $\Phi_{\mathrm{CT}}$, the correlation of the molecular diversity of random $\mathrm{CaMg}$ genotypes within AMF VTUs relative to the correlation of random pairs of genotypes drawn from the entire $\mathrm{CaMg}$ diversity. Statistical significance of the null hypothesis was tested by permutational analysis: 90,000 permuted matrices were generated to obtain the null distribution and to test for the significance of the variance components and the $\Phi$ statistics. 


\section{Detection of recombination}

To detect recombination among $\mathrm{CaMg}$ associated with VTU Gigaspora GAR and VTU Acaulospora that co-occurred spatially, we used the genetic algorithm for recombination detection (GARD) method [35] available through a web interface [36]. GARD searches the sequence alignment for evidence of segment-specific phylogenies and assesses goodness of fit using the small sample $\mathrm{AIC}\left(\mathrm{AIC}_{\mathrm{C}}\right)$ criterion derived from a maximum likelihood model fit to each segment. To verify whether the segment-specific topologies are significantly different, the Kishino-Hasegawa test [37] is conducted. The Kishino-Hasegawa test estimates the variance of the difference between log likelihood scores of two phylogenetic trees.

\section{Results}

\section{AMF and their endobacteria across dune habitats at Cape Cod}

A pilot survey of AMF and their endobacteria across diverse dune habitats at Cape Cod, including foredunes, backdunes, dune-woodland transition, and woodland, yielded 325 AMF isolates (spores). Only $\sim 40 \%$ of these AMF could be genotyped successfully, revealing 10 VTUs (see Materials and methods section) (Fig. 1, Table S2). In terms of abundance, over $75 \%$ of isolates were classified in the family Gigasporaceae, followed by Acaulosporaceae, which accounted for $16 \%$ of isolates. The foredunes were dominated by VTU Gigaspora GAR, which comprised AMF clustering with $G i$. gigantea, Gi. albida and Gi. rosea (Fig. 1). Other Gigasporaceae VTUs stood out as more abundant in the remaining areas of backdunes, dunewoodland transition, and woodland (Table S2). In addition to Gigasporaceae and Acaulosporaceae, we also detected representatives of Diversisporaceae and Glomeraceae, as well as a couple of isolates whose relationship with Paraglomeraceae, Archaeosporaceae, and Ambisporaceae remained unresolved.

$\mathrm{Ca} \mathrm{Gg}$ was found in $7 \%$ of the Gigasporaceae isolates, including VTU Gigaspora GAR, VTU Scutellospora, and VTU Cetraspora (Fig. 2, Table S2). In contrast, $\mathrm{CaMg}$ was found in nearly $50 \%$ of all AMF isolates, including representatives of Gigasporaceae, Acaulosporaceae, and Diversisporaceae (Table S2). Several isolates of Glomeraceae were consistently free of $\mathrm{CaMg}$ (Table S2).

\section{Foredune AMF}

To assess whether environmental factors affect the incidence of endobacteria across AMF, we conducted systematic sampling along four transects spanning a foredune area dominated by A. breviligulata (Figure S1). Of over 1000 AMF spores sampled, 499 could be genotyped and grouped into five VTUs: VTU Gigaspora GAR (68.2\%), VTU Racocetra (22.5\%), VTU Acaulospora (5.4\%), VTU Dentiscutata (3.6\%), and VTU Corymbiglomus $(0.2 \%)$ (Fig. 1, Dataset S1). At the edge of the vegetation line ( $0 \mathrm{~m}$ away from the beach), AMF spores were sparse, and the ones that were isolated oftentimes failed to yield PCR amplicons of an AMF 28S rRNA gene sequence. As a result, there was a low number of AMF sequences obtained at $0 \mathrm{~m}$ away from the beach. VTU Gigaspora GAR dominated the AMF community at all sampling points except at 0 and $70 \mathrm{~m}$ where VTU Acaulospora was dominant (Fig. 3). VTU Racocetra increased in abundance beyond $10 \mathrm{~m}$ from the beach.

\section{Foredune environmental parameters}

Total plant number at sampling points across the foredune study site was inversely proportional to average NND. In other words, as the number of plants at a sampling point increased, distance between them decreased $\left(r^{2}=0.75, P<\right.$ 0.001 , Fig. 4a). Because total number of plants and average distance between them were so tightly correlated, we focused on total plant number as the measure of plant density. We found that plant density decreased slightly with increasing distance from the beach $\left(r^{2}=0.04, P<0.001\right.$, Fig. 4b), and that dominance of $A$. breviligulata also declined with increasing distance from the beach $\left(r^{2}=0.1\right.$, $P<0.001$, Fig. $4 c$ ).

The $\mathrm{pH}$ of soil along the foredune transects ranged from 5.5 to 7.5 , with the average of 6.21 (Table S3). These values, although consistent with what has been previously reported by the National Park Service [38], did not correlate with distance from the beach. Soil salinity, measured as soluble salts (conductivity, mmhos $\mathrm{cm}^{-1}$ ) declined with increasing distance from the beach $\left(r^{2}=0.37, P=0.03\right)$, as did the calcium $\left(r^{2}=0.65, P=0.001\right)$ and sodium $\left(r^{2}=\right.$ $0.45, P=0.01$ ) ion concentrations (Table S3). These patterns were largely expected, because the dune environment is typically characterized by decreasing levels of soil salinity with increasing distance from the shore due to decreased exposure to sea spray [23].

\section{Influence of environmental factors on endobacteria incidence in foredune AMF}

An examination of endobacteria incidence in foredune AMF revealed a striking difference in the abundance of $\mathrm{CaCg}$ and $\mathrm{CaMg}$. $\mathrm{Ca \textrm {Gg }}$ was found in only $2 \%$ of all AMF spores, and was limited to VTU Gigaspora GAR (Fig. 2, Dataset S1). CaMg, on the other hand, was very abundant, 
with $88 \%$ of all AMF spores harboring it, including representatives of the family Gigasporaceae, as well as VTU Acaulospora and VTU Corymbiglomus (Dataset S1). All spores that supported $\mathrm{CaGg}$ also contained $\mathrm{CaMg}$ (Fig. 2), which was not always the case in AMF examined during the pilot survey (Table S2) or in culture collections $[14,15]$. In

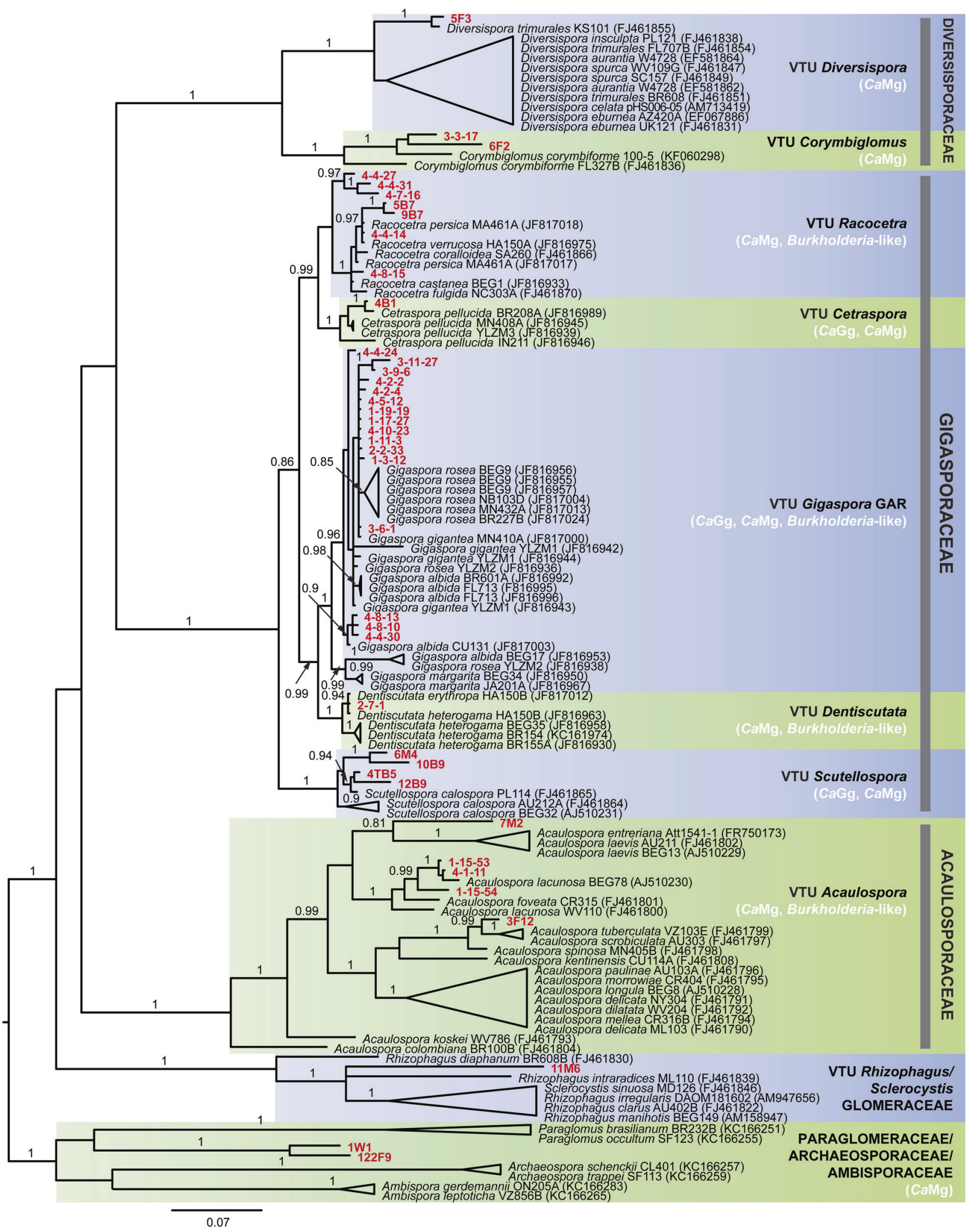


Fig. 1 AMF phylogeny based on the 28S rRNA gene sequence. Taxa in red are representatives of Cape Cod OTUs constructed by clustering at $95 \%$ similarity of sequences retrieved during the 2010 pilot survey and 2013 systematic study; the remaining are reference taxa. 2010 taxon identifiers include spore number, sampling location $(\mathrm{F}$, foredune; $\mathrm{B}$, backdune; $\mathrm{M}$, transition area; $\mathrm{W}$, woodland), and sample number; 2013 taxon identifiers denote transect number, sample number, and spore number. Numbers above branches represent Bayesian posterior probability; values above 0.8 are displayed. The complete phylogeny and sequence alignment are included in Dataset S2

particular, Gigaspora margarita BEG34, a model for the $\mathrm{CaGg-Gigasporaceae} \mathrm{symbiosis,} \mathrm{harbors} \mathrm{CaGg}$ but not $\mathrm{CaMg}[12,14]$.

$\mathrm{CaMg}$ distribution varied among the different foredune AMF VTUs. CaMg was abundant in spores of VTU Gigaspora GAR (90\%), VTU Racocetra (93\%), and VTU Dentiscutata (83\%), and found in less than half of spores of VTU Acaulospora (46\%).

Distribution of $\mathrm{CaGg}$ and $\mathrm{CaMg}$ in foredune $\mathrm{AMF}$ was not significantly affected by distance from the beach. Moreover, none of the environmental parameters that we measured (plant density, A. breviligulata dominance, salinity, $\mathrm{pH}, \mathrm{Ca}$, and $\mathrm{Na}$ soil content) had an impact on $\mathrm{CaMg}$ or $\mathrm{CaGg}$ distribution across all AMF isolates. However, when we modeled effect of environmental parameters on endobacteria distribution in individual VTUs, we found that in VTU Acaulospora, CaMg incidence was correlated with plant density ( $P=0.01$, Fig. 5). These patterns suggest that fungal host identity has an important role in how $\mathrm{CaMg}$ distribution is affected by environmental variables.

\section{CaMg diversity in Cape Cod AMF}

$\mathrm{CaMg}$ is known to exhibit high genetic diversity in culture collection isolates of AMF, often with higher levels of diversity within than among host individuals [11-15]. To determine whether this pattern was also apparent in natural populations of $\mathrm{CaMg}$ from sand dunes, we analyzed $\mathrm{CaMg}$ population structure from two distantly related AMF identified in our samples, VTU Gigaspora GAR and VTU Acaulospora (Fig. 6, Figure S2). Besides being distantly related phylogenetically, these AMF differed in $\mathrm{CaMg}$ incidence, with VTU Gigaspora GAR displaying a much higher $\mathrm{CaMg}$ incidence than VTU Acaulospora (Dataset S1).

To examine $C a \mathrm{Mg}$ diversity, we assessed unique cloned 16S rRNA gene sequences (haplotypes) from different spores of VTU Gigaspora GAR and VTU Acaulospora cooccurring within three soil samples (Fig. 6 and Figure S2). We found that individuals of VTU Gigaspora GAR harbored several deeply divergent $\mathrm{CaMg}$ haplotype clusters, which were interspersed across the phylogeny of $\mathrm{CaMg}$ associated with Acaulosporaceae, Diversisporaceae, and Gigasporaceae (Fig. 6). Conversely, VTU Acaulospora harbored two divergent haplotypes of $\mathrm{CaMg}$ (Fig. 6). AMOVA [34] revealed that the variance component of $\mathrm{CaMg}$ diversity between these two VTUs of AMF was small and, instead, high levels of diversity were apparent within $\mathrm{CaMg}$ populations associated with individual AMF isolates (over $70 \%$ of variance), as well as among isolates within AMF VTUs (over $27 \%$ of variance) (Table S4). The latter pattern resembles partitioning of $\mathrm{CaMg}$ diversity within and among AMF isolates within a geographic region [14].

$\mathrm{CaMg}$ transmission within AMF is predominantly vertical $[11,12]$. However, $\mathrm{CaMg}$ molecular evolution patterns indicate a low level of horizontal transmission [14]. We tested the hypothesis of horizontal transmission in $\mathrm{CaMg}$ by examining the patterns of $16 \mathrm{~S}$ rRNA gene diversity among $C a \mathrm{Mg}$ associated with VTU Gigaspora GAR and VTU Acaulospora co-occurring within the same soil samples (Figure S2), with a particular focus on genetic recombination. GARD [35] revealed no evidence of gene exchanges among $\mathrm{CaMg}$ from these two distantly related hosts that coexisted spatially, suggesting that physical proximity between AMF species is not sufficient for horizontal transmission of $\mathrm{CaMg}$ to occur.

\section{Analysis of $\mathrm{CaGg}$ diversity at Cape Cod reveals previously uncharacterized bacteria}

To date, our knowledge of $C a \mathrm{Gg}$ and $C a \mathrm{Mg}$ population structure comes primarily from analyses of culture collection isolates of AMF [8, 13-15, 39], and little is known about these endobacteria in nature. Using $23 \mathrm{~S}$ rRNA gene sequences PCR amplified with Burkholderia-specific primers, we reconstructed a phylogeny of $\mathrm{CaGg}$ detected at Cape Cod, and discovered a new clade that was distinct from endobacteria in culture collection isolates (Fig. 2). These $\mathrm{CaGg}$ sequences were recovered during both the 2010 pilot survey and the 2013 systematic study (Fig. 2, Table S2, Dataset S1). Interestingly, they shared $99.9 \%$ identity with each other, regardless of the sampling year, indicating a temporally stable population.

In addition to $\mathrm{CaGg}$, Burkholderia-specific PCR primers revealed novel Burkholderiaceae sequences in spores of dune AMF collected during the pilot survey and systematic sampling. These sequences were repeatedly recovered from VTU Gigaspora GAR and VTU Acaulospora spores, and grouped away from the $\mathrm{CaGg}$ (Fig. 2, Table S2, Dataset S2). One of these Burkholderia-related sequences clustered with Mycoavidus cysteinexigens, an endosymbiont of another Mucoromycota fungus, Mortierella elongata [40]. The remaining sequences fell into two clusters, one grouping with free-living Burkholderia and the other 


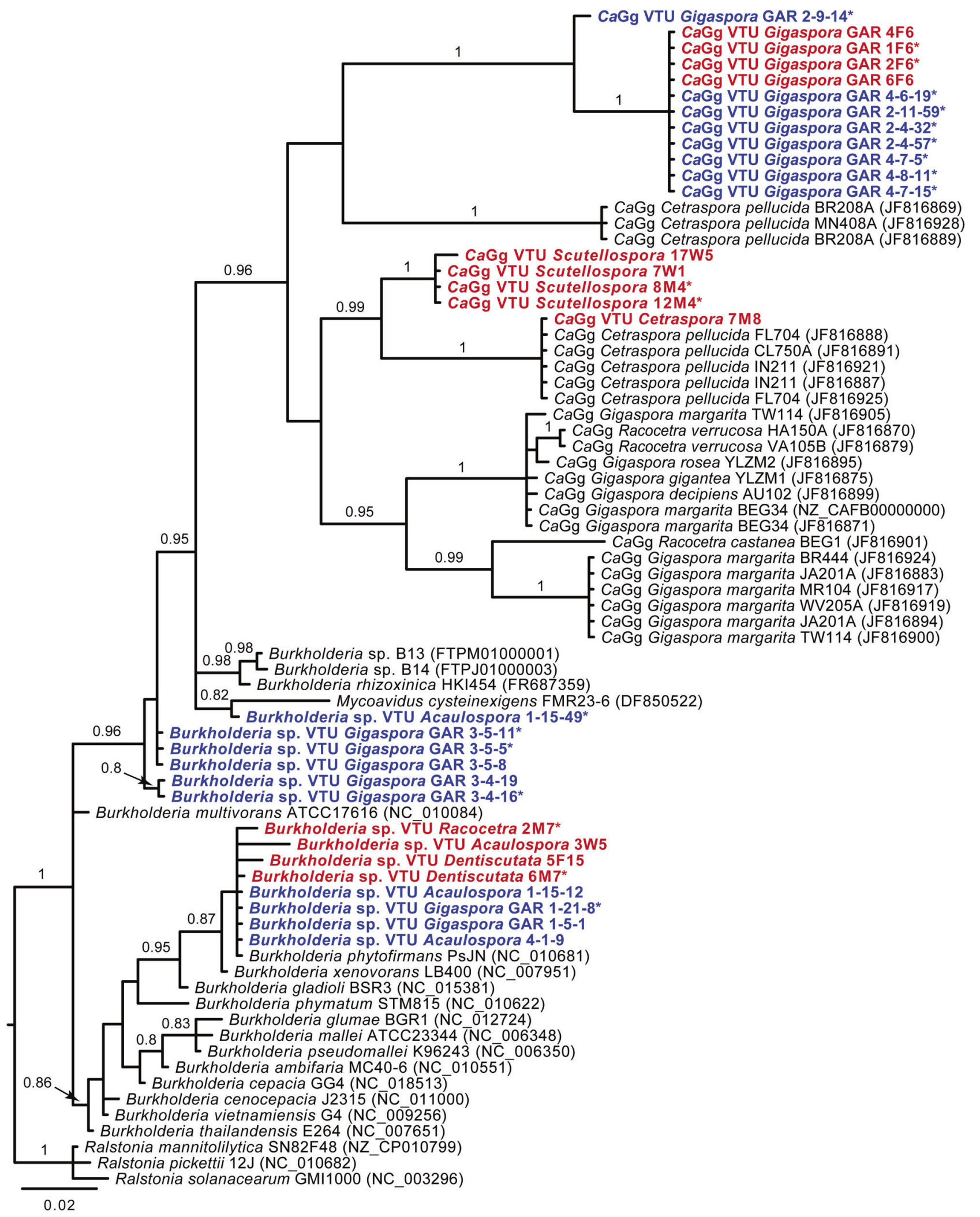

clustering away from both free living and other known endofungal Burkholderia. Considering that we surface decontaminated all spores examined, these bacteria were likely present inside the fungal cells and could represent a new group of endobacteria previously not known to live in AMF. However, fluorescence in situ hybridization 
Fig. 2 Relationships between $\mathrm{CaGg}$, Burkholderia-related endobacteria of Rhizopus microsporus and Mortierella elongata, as well as free-living Burkholderia based on the 23S rRNA gene sequence. Endobacteria marked with asterisks co-existed with $\mathrm{CaMg}$. Taxon identifiers in red represent bacterial sequences obtained from AMF during the 2010 pilot survey, and denote AMF VTU, spore number, sampling location $(\mathrm{F}$, fordune; $\mathrm{B}$, backdune; $\mathrm{M}$, transition area; $\mathrm{W}$, woodland), and sample number. Taxon identifiers in blue represent bacteria found in AMF in 2013, and indicate AMF VTU, transect, and sample number followed by spore number. Numbers above branches represent Bayesian posterior probability, values above 0.8 are shown

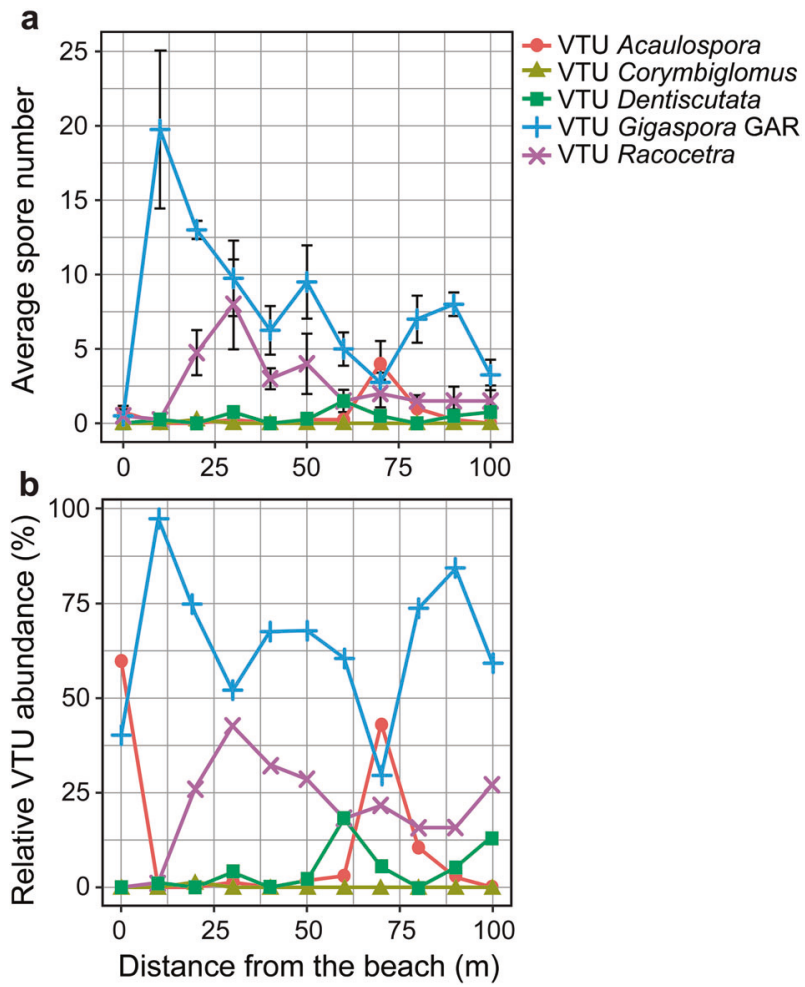

Fig. 3 Abundance and distribution of AMF at the Cape Cod National Seashore foredune study site at varying distances from the beach. a Abundance; error bars represent 1 SEM. b Relative abundance

experiments with Burkholderia-specific probes are needed to confirm this hypothesis.

\section{Discussion}

We found that the foredune North Atlantic study system at Cape Cod, with its nearly monospecific cover of A. breviligulata and steep environmental gradients, was dominated by AMF classified in the families Gigasporaceae and Acaulosporaceae. As these families were reported to dominate the AMF community at Cape Cod in the 1990s [21], our findings indicate that Gigasporaceae and Acaulosporaceae form
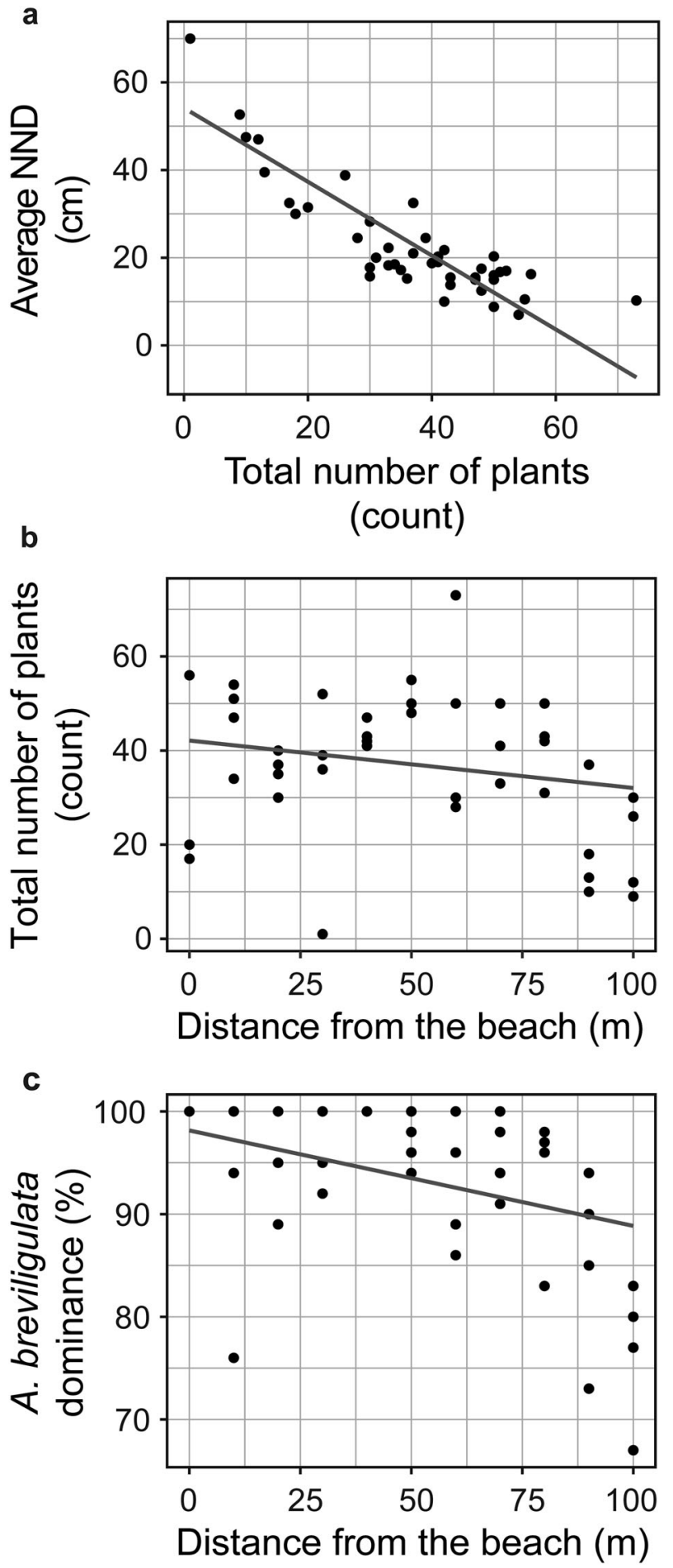

Fig. 4 Vegetation characteristics at the Cape Cod National Seashore foredune study site. a Relationship between average nearest neighbor distance (NND), i.e., average distance to four nearest plants in the 70 $\mathrm{cm}$ radius around the area of soil sampling, and total number of plants in a $70 \mathrm{~cm}$ radius from the sampling point. b Relationship between total number of plants and distance from the beach. c Relationship between dominance of $A$. breviligulata and distance from the beach. Linear regression was used to model the relationships in these graphs 


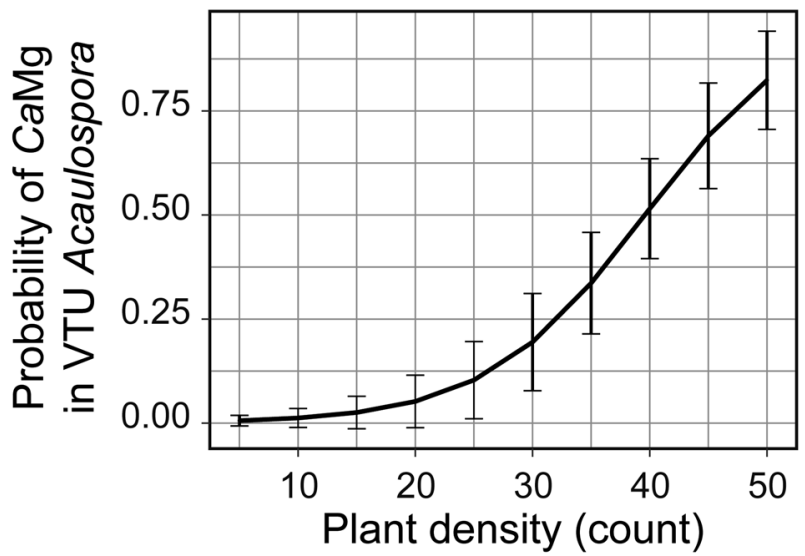

Fig. 5 Distribution of $\mathrm{CaMg}$ in VTU Acaulospora at the Cape Cod foredune study site. Probability of VTU Acaulospora harboring CaMg at different plant density. Error bars represent 1 SEM temporally stable associations with dune vegetation. Despite a high relative abundance of the Gigasporaceae fungi, which have been reported to harbor $\mathrm{CaGg}$ in $>50 \%$ of globally distributed populations [8], this endobacterium turned out to be surprisingly rare, occurring in only $2 \%$ of the Gigasporaceae isolates. In contrast, $\mathrm{CaMg}$ was substantially more evenly distributed across AMF spores.

Evolutionary stability of the $\mathrm{CaGg}$-Gigasporaceae association in its current non-reciprocally obligate state was hypothesized to be the result of shifting environmental pressures, whereby harboring $\mathrm{CaGg}$ is only advantageous under certain circumstances [8]. Given experimental evidence indicating that $\mathrm{CaGg}$ contributes to increased proliferation of AMF pre-symbiotic hyphae that seek out and contact the plant host for symbiosis establishment [6], $\mathrm{CaGg}$ could be expected to be beneficial only under conditions that require extensive pre-symbiotic hyphal growth.

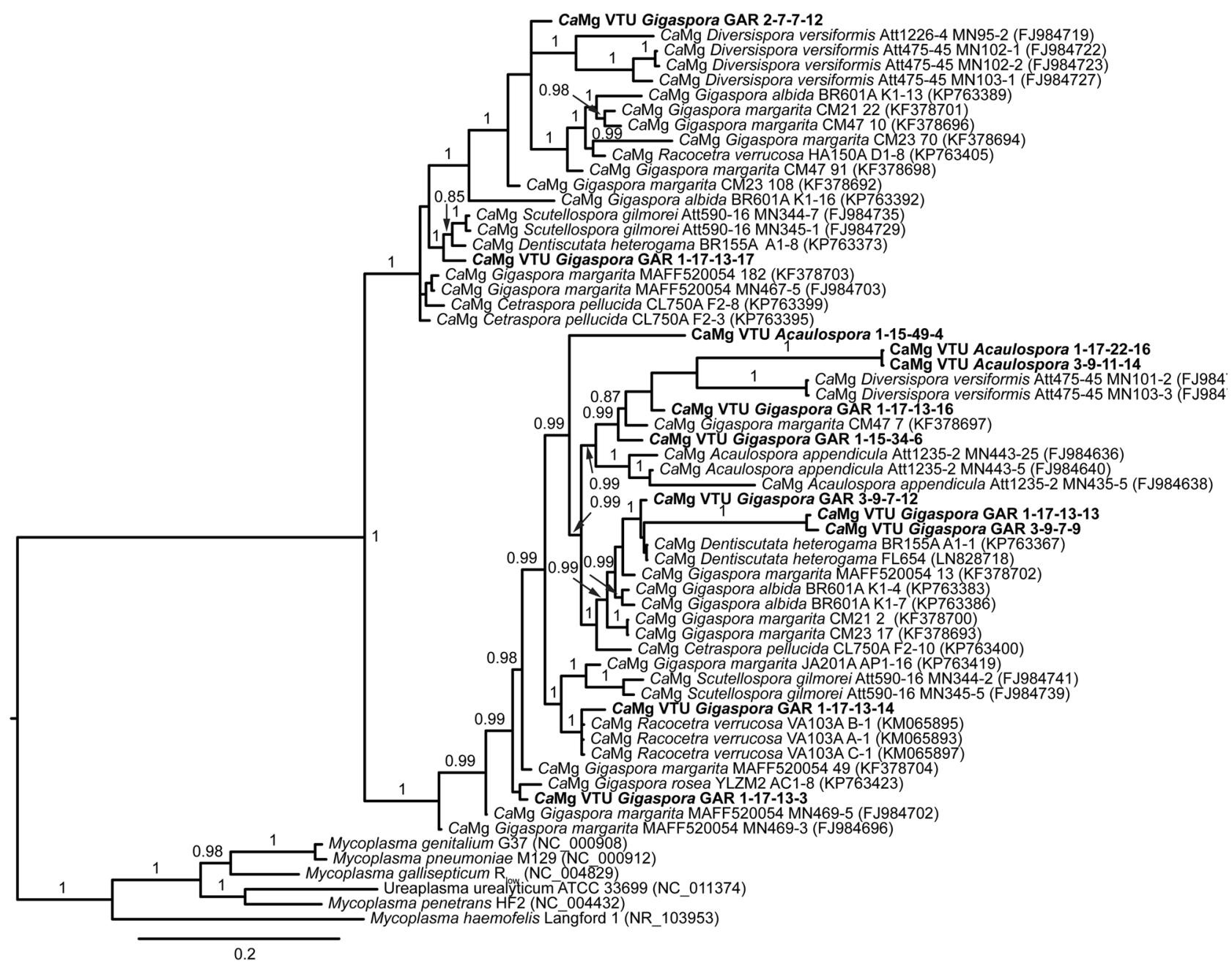

Fig. 6 Phylogeny of $\mathrm{CaMg}$ associated with Gigasporaceae, Acaulosporaceae, and Diversisporaceae based on the 16S rRNA gene sequence. OTUs detected at the Cape Cod foredune study site are in bold. 16S rRNA gene clones were obtained from individual spores of VTU Acaulospora and VTU Gigaspora GAR, and grouped into OTUs at 94\% sequence similarity. Taxon identifiers indicate AMF VTU, sample location (transect, sample number), spore number and clone number. Numbers above branches represent Bayesian posterior probability; values above 0.8 are shown 
Such conditions are likely to occur when chances of a germinating fungal spore to contact its plant host are lowered due to low plant density typified by larger distances between potential plant hosts. In Cape Cod foredunes, plant density declined with increasing distance from the ocean, with larger distances recorded between individual plants. However, we detected no correlation between $\mathrm{CaGg}$ presence in AMF and plant density, suggesting that plant density may not be a factor in determining $\mathrm{CaGg}$ incidence in AMF.

In contrast to $\mathrm{Ca} \mathrm{Gg}, \mathrm{CaMg}$ was extremely abundant in dune AMF. This was largely unexpected, as molecular evolution patterns suggest that $\mathrm{CaMg}$ may be a parasite of AMF [13, 14]. Moreover, there is experimental evidence indicating that endobacteria closely related to $\mathrm{CaMg}$ are conditional parasites of Mortierellomycotina, another group of Mucoromycota fungi [41]. Although the exact role of $\mathrm{CaMg}$ in the biology of AMF has not been established, two evolutionary scenarios could account for the persistence of a heritable parasite in AMF populations: (i) occasional horizontal transmission [42, 43], and (ii) conditional mutualism [44-46].

According to evolutionary theory, some degree of horizontal transmission is important for vertically transmitted symbionts that lower host fitness in antagonistic interactions $[42,43]$. Otherwise, such heritable parasites are unlikely to persist in a host population. Horizontal transmission has been hypothesized to occur in $C a \mathrm{Mg}[13,14,16]$, however, it was never demonstrated experimentally. At Cape Cod we found no evidence of $\mathrm{CaMg}$ mixing between two distantly related AMF that co-occurred within the same soil samples, suggesting that physical proximity is not sufficient to facilitate horizontal transmission of $\mathrm{CaMg}$. Such absence of $\mathrm{CaMg}$ transfer between neighboring hosts suggests that partner genetic factors may have a role in horizontal transmission of $\mathrm{CaMg}$, a hypothesis that remains to be tested.

In the absence of horizontal transmission, persistence of heritable parasites is predicted to depend on their ability to act as conditional mutualists that improve host fitness under specific conditions [44-46]. These specific conditions may be related to resources available to the host $[44,46]$. In habitats with patchy distribution of resources, antagonistic symbionts are expected to persist even if their vertical transmission is imperfect, that is, they are not inherited by all host progeny [46]. In coastal dunes, we found that in VTU Acaulospora, incidence of $\mathrm{CaMg}$ was variable and correlated positively with plant density. If horizontal transmission of $\mathrm{CaMg}$ is indeed absent among dune AMF, this pattern may suggest that $\mathrm{CaMg}$ is a conditional mutualist presenting its AMF hosts with variable fitness outcomes that depend on resource availability represented by host plant density.
Protecting the host from another, more virulent, horizontally transmitted antagonist is another form of conditional mutualism expected to keep heritable parasites from extinction [45]. Although no known horizontally transmitted parasites have been characterized in AMF to date, AMF associate with soil bacteria in the mycorrhizosphere environment, and these bacteria can have both mutualistic and antagonistic/parasitic effects on the fungus [47]. In this context, testing the hypothesis that $\mathrm{CaMg}$ is a conditional defensive mutualist of AMF is likely to unravel a complex network of functionally uncharacterized interactions that AMF form with rhizospheric bacteria. In particular, at Cape $\mathrm{Cod}$, we identified multiple AMF isolates from which we recovered DNA sequences of $\mathrm{CaMg}$ together with DNA of bacteria related to free-living Burkholderia and endobacteria of another Mucoromycota fungus. Future work is needed to confirm the intracellular location of these bacteria, examine their mode of transmission, measure impact on AMF fitness, and characterize interactions with $\mathrm{CaMg}$.

Overall, the effects of environmental factors on incidence of endobacteria across dune AMF differed between the two endosymbionts and were related to the identity of host fungi. $\mathrm{CaGg}$ was rare despite a high relative abundance of its Gigasporaceae hosts, and its distribution was not explained by any environmental variables. $\mathrm{CaMg}$ was common in VTU Gigaspora GAR and less frequent in VTU Acaulospora. Importantly, incidence of $\mathrm{CaMg}$ in VTU Gigaspora GAR was not affected by environmental factors, whereas in VTU Acaulospora, it was favored by increasing plant density. These patterns suggest that fungal host identity is a notable determinant of how $\mathrm{CaMg}$ distribution across AMF responds to environmental variability.

\section{Conclusion}

Our study showed that associations between AMF and their heritable endobacteria are not easily perturbed by shifting environmental conditions that typify costal dunes. We confirmed the existence of heterogeneous populations of $\mathrm{CaMg}$ in $\mathrm{AMF}$ in nature, analogous to what has been reported in culture collection isolates of AMF. However, contrary to our expectation, we found no evidence that $\mathrm{CaMg}$ is horizontally transmitted between distantly related hosts occupying the same habitat. In addition, assessment of endobacteria diversity revealed a novel group of $\mathrm{CaGg}$, as well as a previously unreported group of Burkholderiarelated endobacteria in AMF. Collectively, we conducted the first ecological study of AMF-associated endobacteria and assessed their diversity and population structure.

Acknowledgements We are grateful to D. Moebius-Clune for discussions about sampling design, M. Barker and J. Olds for assistance 
in sample collection, and the National Park Service for permission to collect samples at Cape Cod National Seashore. We thank two anonymous reviewers for helpful comments. This work was supported by the National Science Foundation grants DEB-0918880, IOS1261004, and DBI-1263103 to TEP, National Science Foundation Biology Research Fellowship DBI-0933921 to KHT, and the Frederic N. Gabler'93 Memorial Research Endowment grant to EA.

\section{Compliance with ethical standards}

Conflict of interest The authors declare that they have no conflict of interest.

\section{References}

1. Smith SE, Read DJ. Mycorrhizal symbiosis. Third ed. New York: Academic Press; 2008.

2. Gianinazzi S, Gollotte A, Binet MN, van Tuinen D, Redecker D, Wipf D. Agroecology: the key role of arbuscular mycorrhizas in ecosystem services. Mycorrhiza. 2010;20:519-30.

3. Weber OB. Biofertilizers with arbuscular mycorrhizal fungi in agriculture. In: Solaiman ZM, Abbott LK, Varma A, editors. Mycorrhizal fungi: use in sustainable agriculture and land restoration. Berlin, Heidelberg: Springer; 2014. p. 45-66.

4. Mosse B. Honey-coloured, sessile Endogone spores: II. Changes in fine structure during spore development. Arch Microbiol. 1970;74:129-45.

5. Bianciotto V, Lumini E, Bonfante P, Vandamme P. 'Candidatus Glomeribacter gigasporarum' gen. nov., sp nov., an endosymbiont of arbuscular mycorrhizal fungi. Int $\mathrm{J}$ Syst Evol Microbiol. 2003;53:121-4.

6. Lumini E, Bianciotto V, Jargeat P, Novero M, Salvioli A, Faccio A, et al. Presymbiotic growth and sporal morphology are affected in the arbuscular mycorrhizal fungus Gigaspora margarita cured of its endobacteria. Cell Microbiol. 2007;9:1716-29.

7. Salvioli A, Ghignone S, Novero M, Navazio L, Venice F, Bagnaresi $\mathrm{P}$, et al. Symbiosis with an endobacterium increases the fitness of a mycorrhizal fungus, raising its bioenergetic potential. ISME J. 2016;10:130-44.

8. Mondo SJ, Toomer KH, Morton JB, Lekberg Y, Pawlowska TE. Evolutionary stability in a 400-million-year-old heritable facultative mutualism. Evolution. 2012;66:2564-76.

9. Jargeat P, Cosseau C, Ola'h B, Jauneau A, Bonfante P, Batut J, et al. Isolation, free-living capacities, and genome structure of "Candidatus Glomeribacter gigasporarum," the endocellular bacterium of the mycorrhizal fungus Gigaspora margarita. J Bacteriol. 2004;186:6876-84.

10. Ghignone S, Salvioli A, Anca I, Lumini E, Ortu G, Petiti L, et al. The genome of the obligate endobacterium of an AM fungus reveals an interphylum network of nutritional interactions. ISME J. 2012;6:136-45.

11. Naito M, Desirò A, Gonzalez JB, Tao G, Bonfante P, Morton JB, et al. 'Candidatus Moeniiplasma glomeromycotorum', an endobacterium of arbuscular mycorrhizal fungi. Int J Syst Evol Microbiol. 2017;67:1177-84.

12. Naumann M, Schüßler A, Bonfante P. The obligate endobacteria of arbuscular mycorrhizal fungi are ancient heritable components related to the Mollicutes. ISME J. 2010;4:862-71.

13. Naito M, Morton JB, Pawlowska TE. Minimal genomes of mycoplasma-related endobacteria are plastic and contain hostderived genes for sustained life within Glomeromycota. Proc Natl Acad Sci USA. 2015;112:7791-6.

14. Toomer KH, Chen X, Naito M, Mondo SJ, den Bakker HC, VanKuren NW, et al. Molecular evolution patterns reveal life history features of mycoplasma-related endobacteria associated with arbuscular mycorrhizal fungi. Mol Ecol. 2015;24: 3485-3500

15. Desirò A, Salvioli A, Ngonkeu EL, Mondo SJ, Epis S, Faccio A, et al. Detection of a novel intracellular microbiome hosted in arbuscular mycorrhizal fungi. ISME J. 2014;8:257-70.

16. Naito M, Pawlowska TE. Defying Muller's ratchet: heritable endobacteria escape extinction through recombination and genome plasticity. mBio. 2016;7:e02057-02015.

17. Gemma JN, Koske RE, Carreiro M. Seasonal dynamics of selected species of VA mycorrhizal fungi in a sand dune. Mycol Res. 1989;92:317-21.

18. Koske RE. A preliminary study of interactions between species of vesicular-arbuscular fungi in a sand dune. Trans $\mathrm{Br}$ Mycol Soc. 1981;76:411-6.

19. Koske RE, Halvorson WL. Ecological studies of vesiculararbuscular mycorrhizae in a barrier sand dune. Can $\mathrm{J}$ Bot. 1981;59:1413-22.

20. Koske RE. Distribution of VA mycorrhizal fungi along a latitudinal temperature gradient. Mycologia. 1987;79:55-68.

21. Koske RE, Gemma JN. Mycorrhizae and succession in plantings of beachgrass in sand dunes. Am J Bot. 1997;84:118-30.

22. Gemma JN, Koske RE. Seasonal variation in spore abundance and dormancy of Gigaspora gigantea and in mycorrhizal inoculum potential of a dune soil. Mycologia. 1988;80:211-6.

23. Hesp PA, Martinez ML. Disturbance processes and dynamics in coastal dunes. In: Johnson EA, Miyanishi K, editors. Plant disturbance ecology: the process and the response. Burlington, MA: Academic Press; 2007. p. 215-47.

24. Kucinski KJ, Eisenmenger WS. Sand dune stabilization on Cape Cod. Econ Geogr. 1943;19:206-14.

25. Cheplick GP. Patterns in the distribution of American beachgrass (Ammophila breviligulata) and the density and reproduction of annual plants on a coastal beach. Plant Ecol. 2005;180:57-67.

26. Daniels BA, Skipper HD. Methods for the recovery and quantitative estimation of propagules from soil. In: Schenck NC, editor. Methods and principles of mycorrhizal research. St. Paul, MN: The American Phytopathological Society; 1982. p. 29-35.

27. Moebius-Clune DJ, Anderson ZU, Pawlowska TE. Arbuscular mycorrhizal fungi associated with a single agronomic plant host across the landscape: the structure of an assemblage. Soil Biol Biochem. 2013;64:181-90.

28. Schloss PD, Westcott SL, Ryabin T, Hall JR, Hartmann M, Hollister EB, et al. Introducing mothur: open-source, platformindependent, community-supported software for describing and comparing microbial communities. Appl Environ Microb. 2009;75:7537-41.

29. Van Tuinen D, Jacquot E, Zhao B, Gollotte A, Gianinazzi-Pearson V. Characterization of root colonization profiles by a microcosm community of arbuscular mycorrhizal fungi using 25S rDNAtargeted nested PCR. Mol Ecol. 1998;7:879-87.

30. Edgar RC. MUSCLE: multiple sequence alignment with high accuracy and high throughput. Nucleic Acids Res. 2004; 32:1792-7.

31. Bianciotto V, Genre A, Jargeat P, Lumini E, Becard G, Bonfante P. Vertical transmission of endobacteria in the arbuscular mycorrhizal fungus Gigaspora margarita through generation of vegetative spores. Appl Environ Microb. 2004;70:3600-8.

32. Ronquist F, Teslenko M, van der Mark P, Ayres DL, Darling A, Höhna S, et al. MrBayes 3.2: efficient Bayesian phylogenetic inference and model choice across a large model space. Syst Biol. 2012;61:539-42.

33. Moebius-Clune BN, Moebius-Clune DJ, Gugino BK, Idowu OJ, Schindelbeck RR, Ristow AJ, et al. Comprehensive assessment of soil health: the Cornell framework. Ithaca, NY: Cornell University; 2017. 
34. Excoffier L, Laval G, Schneider S. Arlequin (version 3.0): an integrated software package for population genetics data analysis. Evol Bioinform. 2005;1:47-50.

35. Kosakovsky Pond SL, Posada D, Gravenor MB, Woelk CH, Frost SDW. GARD: a genetic algorithm for recombination detection. Bioinformatics. 2006;22:3096-8.

36. Delport W, Poon AFY, Frost SDW, Kosakovsky Pond SL. Datamonkey 2010: a suite of phylogenetic analysis tools for evolutionary biology. Bioinformatics. 2010;26:2455-7.

37. Kishino H, Hasegawa M. Evaluation of the maximum-likelihood estimate of the evolutionary tree topologies from DNA sequence data, and the branching order in Hominoidea. J Mol Evol. 1989;29:170-9.

38. Smith SM. Dune vegetation monitoring. Wellfleet, MA: National Park Service, Cape Cod National Seashore; 2006.

39. Mondo SJ, Salvioli A, Bonfante P, Morton JB, Pawlowska TE. Nondegenerative evolution in ancient heritable bacterial endosymbionts of fungi. Mol Biol Evol. 2016;33:2216-31.

40. Ohshima S, Sato Y, Fujimura R, Takashima Y, Hamada M, Nishizawa T, et al. Mycoavidus cysteinexigens gen. nov., sp. nov., an endohyphal bacterium isolated from a soil isolate of the fungus Mortierella elongata. Int J Syst Evol Microbiol. 2016;66:2052-7.
41. Desirò A, Hao Z, Liber JA, Benucci GMN, Lowry D, Roberson R, et al. Mycoplasma-related endobacteria within Mortierellomycotina fungi: diversity, distribution and functional insights into their lifestyle. ISME J. 2018. https://doi.org/10.1038/s41396018-0053-9.

42. Fine PEM. Vectors and vertical transmission: an epidemiologic perspective. Ann NY Acad Sci. 1975;266:173-94.

43. Lipsitch M, Nowak MA, Ebert D, May RM. The population dynamics of vertically and horizontally transmitted parasites. Proc Roy Soc Lond B Bio. 1995;260:321-7.

44. Gyllenberg M, Preoteasa D, Saikkonen K. Vertically transmitted symbionts in structured host metapopulations. B Math Biol. 2002;64:959-78.

45. Lively CM, Clay K, Wade MJ, Fuqua C. Competitive coexistence of vertically and horizontally transmitted parasites. Evol Ecol Res. 2005;7:1183-90.

46. Saikkonen K, Ion D, Gyllenberg M. The persistence of vertically transmitted fungi in grass metapopulations. Proc Roy Soc Lond B Bio. 2002;269:1397-403.

47. Johansson JF, Paul LR, Finlay RD. Microbial interactions in the mycorrhizosphere and their significance for sustainable agriculture. FEMS Microbiol Ecol. 2004;48:1-13. 